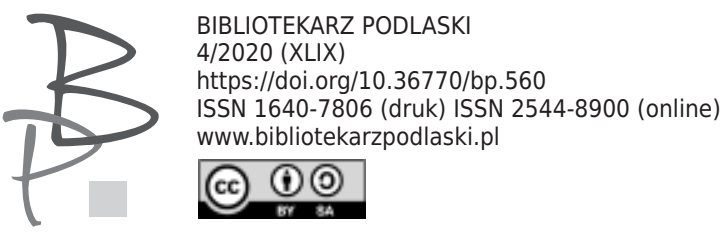

Agnieszka Juchniewicz*

Uniwersytet w Białymstoku

https://orcid.org/0000-0003-2458-9780

\title{
Kategoria komizmu w poetyce sztuk Olega Bogajewa: problem przekroczenia granicy
}

The category of comedy in the poetics of Oleg Bogajew's plays: the problem of crossing the border

Abstract: The purpose of the article was to discuss the problem of crossing the border, which explores the category of comedy in contemporary Russian drama. Based on the plays by Oleg Bogajew from the collection of the Russian People's Post: Who Killed M. d'Anthes, Dead Ears and Stanisławski's Hell, it was determined how the limits of language norms, the real and fantasy world, the sphere of the sacred and the profane, and many others were exceeded. The category of comedy in Bogajew's plays was realized in various forms. Comedy was expressed in both the plot and the character's behavior and expression.

Keywords: comic, laughter, border, Bogajew, contemporary drama.

Agnieszka Juchniewicz - mgr, doktorantka w zakresie literaturoznawstwa na Uniwersytecie w Białymstoku (Wydział Filologiczny, Instytut Studiów Wschodniosłowiańskich). Autorka publikacji Podmiot groteskowy w sztukach Olega Bogajewa (,Studia Rossica Posnaniensia” 2020). 
Kategoria komizmu we współczesnej dramaturgii rosyjskiej jest jedną z dziedzin kultury, budzących szerokie zainteresowanie wśród wielu badaczy, którzy w swoich pracach przedstawiają różne teorie i definicje komiczności ${ }^{1}$. Fascynacja i próby zdefiniowania komicznego sięgają jeszcze czasów starożytnych. Autorami najpopularniejszych teorii są między innymi Artur Schopenhauer, Henri Bergson, Zygmunt Freud, Michał Bachtin, Wissarion Bieliński, Bohdan Dziemidok².

Temat komiczności zaczęto systematycznie opracowywać w wieku XIX (estetyka romantyzmu i niemiecka filozofia klasyczna), natomiast dynamiczny rozwój w omawianym obszarze badań odnotowano w drugiej połowie XX wieku³. Należy zaznaczyć, że na przełomie wieków XX i XXI, a więc wraz ze zmianą epoki, zmieniały się również wzajemne relacje komizmu (będącego fenomenem estetyki) oraz gatunku komedii. Obecnie ich korelacja jest niestabilna i elastyczna, ulega ciągłej zmianie. Dramat współczesny ściśle łączy się z kulturą postmodernistyczną: dekonstrukcja, brak dominanty kompozycyjnej czy liniowość w rezultacie wywołują zjawisko komizmu, niejednokrotnie przekraczające granice absurdu.

Znany badacz estetyki komizmu Bohdan Dziemidok podkreśla, iż od „zasadniczych form komizmu, będących wyrazem pewnej postawy wobec życia, należałoby odróżnić elementarne formy komizmu, będące w gruncie rzeczy środkami wyrazowymi, sposobami czy technikami wywoływania komizmu"4.

1 Wybrane problemy komizmu podejmują m.in. Н.С. Бандурина, Особенности интерпретации феномена комического в историко-литературном и философском контексте, „Вестник Ивановского государственного энергетического университета” 2011, nr 3, s. 1-6; J. Wachowski, O komizmie, śmieszności i nie tylko...[w:] Ko-mediana, Poznań 2013, s. 13-25; Е.В. Гришанова, Социокультурна многоаспектность и историзм категории комического, „Культура и цивилизация” 2017, nr 2(6), s. 102-107.

2 A. Schopenhauer, Świat jako wola i przedstawienie, t. 1, przeł. J. Garewicz, Warszawa 1994; H. Bergson, Śmiech. Esej o komizmie, przeł. S. Cichowicz, Warszawa 1995; Z. Freud, Dowcip i jego stosunek do nieświadomości, przeł. R. Reszke, Warszawa 1993; M. Bachtin, Twórczość Franciszka Rabelais'go, przeł. A. i A. Goreniowie. Warszawa 1982; W. Bieliński, Собрание сочинений в 3 mомах, Moskwa 1948; B. Dziemidok, O komizmie, Warszawa 1967.

3 Н.С. Бандурина, Особенности интерпретации феномена комического, dz. cyt., s. 2.

4 B. Dziemidok, O komizmie, Warszawa 1967, s. 93. 
Należą do nich między innymi: ironia, dowcip, żart, karykaturowanie, parodiowanie, groteskowość, trawestowanie i inne.

Ironia oraz groteska, służące wywołaniu komicznego efektu, są nieodłącznym elementem świata przedstawionego współczesnego dramatu ${ }^{5}$. Краткий словарь по эстетике podaje, że komizm jest to:

\section{[...] одна из основных эстетических категорий, отражающая жизненные} явления, характеризующиеся внутренней противоречивостью, несоответствием между тем, чем они являются по существу, и тем, за что они себя выдают. [...] Комическое является специфической формой раскрытия и оценки общественных противоречий. [...] В комическом сконцентрирован многообразный опыт общественного сознания, осваивающего и познающего мир со стороны его негативных проявлений, в особенности мир социальный, в соотношении с общепринятыми нормами и ценностями 6 .

Należy tu również przywołać idee Michała Bachtina, który rozpatrywał estetykę komizmu w nurcie ,jednolitej ludowej kultury śmiechu” (w szczególności jego koncepcji karnawalizacji). Badacz uważał, że początkowo śmiech karnawałowy i śmiech archaiczny zawierały w sobie wszystkie formy komizmu. Proces dyferencjacji owej kultury śmiechu doprowadził do jego zredukowania, co z kolei wpłynęło na pojawienie się form takich jak humor, ironia, satyra czy sarkazm. Warto podkreślić, iż teoria karnawału Bachtina stała się podstawą socjokulturowej teorii komizmu w pracach jego następców. Bachtin przeanalizował ogromną część niżowej sfery komizmu w kontekście wyobrażeń o demokratyzacji kultury średniowiecza7 ${ }^{7}$ W ten sposób oddzielił on sferę wysoką od sfery profanum w odniesieniu do komizmu oraz bliskiej mu groteski czy ironii, zwracając tym samym uwagę na cechy indywidualne obrazu świata poszczególnych utworów. Charakterystyki komizmu, właściwe literaturze wielu epok, przeanalizowane w pracach Bachtina,

5 Więcej na ten temat znajdziemy między innymi [w:] М. Липовецкий, Б. Боймерс, Перформансы насилия. Литературные и театральные эксперименты «новой драмыл», Москва 2012.

6 Краткий словарь по эстетике, под. ред. М.Ф. Овсянникова, Москва 1983, с. 72.

7 Na ten temat przeczytamy [w:] M. Bachtin, Twórczość Franciszka Rabelais'go a kultura ludowa średniowiecza i renesansu, Kraków 1975. 
Bergsona i innych, odsłaniają wyobrażenie o przekraczaniu różnych granic (w relacjach socjalno-psychologicznych, antropologiczno-kulturowych czy językowych). W kulturze postmodernizmu szczególnego znaczenia nabrało pojęcie transgresji (rozumiane jako przekroczenie granicy), będące jedną $\mathrm{z}$ cech komizmu.

Definiując pojęcie granicy, Nikołaj Rymar podkreśla, że nie można podać jej jednego, sprecyzowanego wyjaśnienia: „Границы в жизни человека - это универсальные или конкретные упорядоченности, которые задают условия бытия человека, это пределы, рамки необходимостей, порядка, закона, жизненного уклада, правил, долга, морали, а также желания и страсти. Это то, что сильнее нас, так как определяет нас, правит, руководит нами извне и изнутри" czenie granicy zawarte jest w języku, we wzajemnych relacjach pomiędzy jego elementami, a widoczne jest to na wszystkich poziomach językowych: fonetycznym, morfologicznym, syntaktycznym, stylistycznym oraz na poziomie tekstu z jego gramatyką ${ }^{9}$. Granica sama w sobie nie jest formą, lecz realizuje się w formach jako ich „[...] смысловое, ценностное основание, обеспечивающее глубинную смысловую иденточность явления" 10 .

Idea granicy w dramaturgii współczesnej eksponuje kategorię komiczności. To, co śmieszy czytelnika, wykracza poza wszelkie ramy, przełamuje bariery norm moralnych, kulturowych i językowych, a tym samym wywołuje u niego tzw. przeżycia ekstatyczne. Rymar wyjaśnia, że już samo pojęcie ekstatyczności wskazuje na wyjście „poza” określone normy: „Идея поэтики экстатического охватывает комплекс представлений о формах построения художественного образа, моделирующих ситуацию отрицания или игнорирования нормы, связанной с представлениями о некоторых фундаментальных основах мироустройства и человеческого бытия в целом [...]"11. Całkowite zniesienie granic otwiera przed człowiekiem niekontrolowaną przestrzeń, nicość, pozwala na to, by w jego duszy zapanował chaos. Badacz uważa, iż eksta-

8 Н. Рымарь, Поэтика границь в литературе. Эстетические и поэтологические аспекты проблемы гранищы как феномена художественного языка, Седльце 2016, s. 7.

9 Tamże, s. 20.

10 Tamże.

11 Tamże, s. 244. 
za powinna w tym kontekście być rozumiana jako „универсальное действие или переживание, связанное с переходом в ту реальность, где категории разума, морали, истины, красоты как категории человеческой культуры перестают существовать [...]"12. Przeżycia ekstatyczne są w pewnym stopniu bliskie śmiechowi, choć bardziej dramatyczne. Oznaczają bowiem przejście w sferę, gdzie nie ma języka ani żadnych podstawowych wyobrażeń człowieka o świecie realnym. Śmiech jest nie tylko psychofizjologiczną reakcją, uwarunkowaną określonymi przeżyciami, ale i fenomenem kultury, związanym z mechanizmami naruszenia granic naszych poglądów ${ }^{13}$.

Nad problemem dyferencjacji śmiesznego i komicznego pochylił się między innymi Henri Bergson, dając jednocześnie podstawę do właściwego rozumienia i rozróżniania tych pojęć. Przedstawione przez niego podejście antropologiczne określiło parametry współczesnej estetyki komizmu ${ }^{14}$. Temat śmiechu w kontekście naruszenia/przekroczenia granicy poruszał także niemiecki filozof i socjolog Helmuth Plessner. Jego filozoficzno-antropologiczna teoria śmiechu i płaczu skupia się wokół specyficznych form ludzkiej ekspresji. Badacz tworzy tak zwaną hermeneutykę cielesności: mimikę, śmiech i płacz określa jako mimowolne formy wyrażania przeżyć, ekspresji. Filozof widzi w tych reakcjach specyficzne fenomeny, ponieważ człowiek osiąga wtedy granice swej ekspresyjności, reaguje żywo całym sobą ${ }^{15}$. W ramach swej teorii Plessner opisuje zachowanie człowieka jako świadome, czy też kontrolowane świadomością. Śmiech i płacz określa jako reakcje, w których to zachowanie się zmienia: „Смех и плач - это реакции на границы, с которыми сталкивается наше поведение. Они имеют скорее принципиальный характер и связаны со структурой человеческого поведения как таковой. То, что идет с ней вразрез... потому, что оно само по себе в принципе отменяет и отвергает поведение, - то и вызывает смех и плач"16. Zdaniem filozofa, zmiana świadomego zachowania wynika z dezorganizacji socjalnej struktury cielesnej egzystencji. Jacek Wachowski śmiech określa jako

12 Tamże, s. 250.

13 Tamże, s. 246.

14 H. Bergson, Śmiech. Esej o komizmie, przeł. S. Cichowicz, Warszawa 1995, s.11.

15 Н.И. Ищенко, Хельмут Плеснер: Смех и плач, 2014, s. 66 [online, 01.09.2019].

16 Tamże, s. 68. 
formę bezinteresownego poznania (w ślad za Bergsonem), komizm zaś nazywa rodzajem intelektualnego przetworzenia śmieszności, który formalizuje śmiech i wprowadza do komunikacyjnego obiegu ${ }^{17}$. Kluczowa różnica pomiędzy śmiechem a komizmem polega na tym, że „to, co niezaplanowane i przypadkowe, jest ze swej natury przednarracyjne, a to, co zaplanowane i przygotowane - przeciwnie, narracyjne" ${ }^{18}$. W tym wypadku śmiech można określić jako przednarracyjny, ponieważ jest nieprzewidywalny i zaskakujący. Komizm natomiast jest efektem pewnych planów i przygotowań. Śmieszne i komiczne różnią się także kształtem narracji. O tym, co śmieszne, decyduje odbiorca, lecz dopiero po zakończeniu zdarzeń - jest to tak zwana narracja aposterioryczna. Konstrukcje komiczne mają charakter aprioryczny, gdyż są uprzednio wyreżyserowane oraz nastawione na wywołanie określonego efektu-rozbawienie odbiorców ${ }^{19}$.

Estetyka komizmu nabrała nowego znaczenia w sztukach przedstawicieli „nowego dramatu”, a w tym również Olega Bogajewa. Charakterystycznymi cechami tego kierunku są między innymi groteskowość, niejednokrotnie absurdalność przedstawionego obrazu świata czy fragmentaryczność zdarzeń. Utwory Bogajewa wyróżniają się wśród pozostałych współczesnych mu dramatów już na poziomie tytułów, w których autor podkreśla ich przynależność do gatunku komedii. Przede wszystkim są one niezwykle emocjonujące, skłaniają odbiorcę do osobliwych przeżyć, odznaczają się oryginalnym stylem i specyficznym językiem. Komizm w tych sztukach rozprzestrzenia się na wszystkie poziomy poetyki tekstu, a także odgrywa kluczową rolę w kształtowaniu obrazu świata. Zdaniem Łarisy Kisłowej, komiczność jako kluczowy sposób organizacji świata przedstawionego w dramaturgii Olega Bogajewa posiada szczególnie pozytywną energię: śmiech stwarza atmosferę karnawału, która w następstwie prowadzi do oczyszczenia (katharsis) ${ }^{20}$.

W dalszej części pracy komedie współczesnego dramaturga zostaną przeanalizowane $\mathrm{w}$ odniesieniu do estetyki komedii XIX/XX wieku (śmiech sta-

17 J. Wachowski, O komizmie, śmieszności i nie tylko..., [w:] Ko-mediana, Poznań 2013, s. 15.

18 Tamże, s. 17.

19 Tamże, s. 18.

20 Л.С. Кислова, Функиии комического в драматургии О. Богаева, „Вестник ТГПУ” $\mathrm{nr} 7$ (109), s. 179 [online, 05.09.2019]. 
nowił wtedy aktywną broń do walki przeciw fałszywym ideałom ${ }^{21}$ ), gdyż są one bliższe sposobowi myślenia i postmodernistycznej wizji dramaturga. $\mathrm{Na}$ podstawie interpretacji utworów ze zbioru Rosyjska poczta ludowa (Русская народная почта): Kto zabit monsieur d'Anthesa. Komedia $w$ dwóch aktach (Кто убил мсье Дантеса. Комедия в двух действиях), Martwe иszy, сzуli historia papieru toaletowego (Мёртвые уши или история туалетной бумаги) oraz Piekło Stanisławskiego. Zwykta historia w jednym akcie (Adъ Станиславского. Обычная история в одном действии), możliwe będzie określenie sposobów przekroczenia granic w relacji podmiot-obiekt, sferach sacrum i profanum, kategorii znaczące-znaczone oraz wiele innych.

W dramacie Kto zabit monsieur d'Anthesa. Komedia w dwóch aktach głównymi postaciami są Aleksander Puszkin oraz Georges-Charles d'Anthes ${ }^{22}$. Zanim jednak poznajemy ich imiona, pierwsze repliki wypowiadają jako Głos i Człowiek. Głos daje się tylko usłyszeć. Dopóki nie zobaczymy, skąd się wydobywa, pozostaje anonimowy. Zadaje pytanie, nawiązując tym samym rozmowę z Człowiekiem: „ГОЛОС. Кто здесь?..”23. Głos należy do pewnego Mężczyzny, tak też autor nazywa tę postać. Zaimek „kto” pojawia się kilkakrotnie. Tym samym wskazuje na nieokreśloność podmiotu, brak jego indywidualizacji. Wzbudza niepewność czytelnika, który nie wie, kogo się spodziewać. Już w samym tytule sztuki zastanawiamy się, kim jest zabójca barona d'Anthesa. Człowiek, chcąc się dowiedzieć, gdzie znajdzie gospodarza, w odpowiedzi słyszy niejasne, trudne do zrozumienia komunikaty. Wielokrotne powtórzenie zmienia związek między obrazem dźwiękowym zaimka a jego znaczeniem:

МУЖЧИНА. Кто мне сказал, я поверил... “Кто”, понимаете?!..

ЧЕЛОВЕК. Мсье, это 26 квартира?!..

МУЖЧИНА. Кто - это он. У него такое странное имя ... Кто. Кто ... Кто. Его зовут - Кто.

ЧЕЛОВЕК. Я ищу хозяина..

21 Е.В. Гришанова, Социокультурна многоаспектность и историзм категории комического, „Культура и цивилизация” 2017, nr 2(6), s. 106 [online, 05.09.2019].

22 Duet, znany z XIX wieku z racji pojedynku, w którym d'Anthes śmiertelnie ranił Puszkina w brzuch. Mimo to, Aleksander Puszkin oddał jeszcze strzał, trafiając przeciwnika w rękę.

23 Ten i kolejne cytaty sztuk Bogajewa pochodzą ze zbioru 13 komedii Русская народная noчma, dostępnego na stronie internetowej: http://bogaev.narod.ru/doc/book.pdf 
МУЖЧИНА. Я не видел Кто две недели!.. Он уехал ... Куда? А Бог знает куда!..

Komizm pojawia się tu w wypowiedziach bohaterów. W tekście sztuki znajdujemy wiele znaków zapytania i ogólników, które niejednokrotnie się powtarzają. Według Bergsona powtórzenie jest jednym z chwytów komedii klasycznej24. Powtarzają się nie tylko określone słowa, frazy, ale też okoliczności, sytuacje, na przykład, kiedy Mężczyzna pyta Człowieka, skąd pochodzi:

МУЖЧИНА. Вы из России?..

ЧЕЛОВЕК. Да.

МУЖЧИНА. Вы из России?!..

ЧЕЛОВЕК. Да.

МУЖЧИНА. ВЫ из России?!!..

ЧЕЛОВЕК. ГОВорю - да.

МУЖЧИНА. Из России..

ЧЕЛОВЕК. Из России... А что.. Похоже?..

МУЖЧИНА (внимательно разглядывает человека). Из России..

Od tej pory bohater, nazywany Człowiekiem, staje się Człowiekiem z Rosji. Gdy ponownie pyta o gospodarza, okazuje się, że umarł dawno temu, a Mężczyzna jest jego synem. Przedstawia się jako Жорж Шарль Дантес:

МУЖЧИНА. Я его сын.

Молчание.

ЧЕЛОВЕК (снимает шляпу). ВЫ его сын???

МУЖЧИНА. Я его сын.

ЧЕЛОВЕК. Вас зовУт?...

МУЖЧИНА. Жорж Шарль ДАНТЕС..

ЧЕЛОВЕК. Жорж Шарль ДАНТЕС?!..

МУЖЧИНА. Жорж Шарль ДАНТЕС.

24 А. Бергсон, Смех, 1992, s. 50 [online, 30.08.2019]. 
Postać d'Anthesa pojawiła się w Bogajewowskiej sztuce wyłącznie jako pojęcie, obiekt zainteresowania, wywołujący literackie skojarzenia. Ewidentnie nie ma nic wspólnego z realną postacią francuskiego barona, co w efekcie staje się głównym źródłem komizmu. Występuje ona jedynie jako Głos i Mężczyzna, nie ma jej jako Człowieka ${ }^{25}$. Kategoria komizmu została wyeksponowana na podstawie planu bohater - postać - głos. Możemy tu mówić o relacjach podmiotu z obiektem, a nawet o znacznym przekroczeniu tej granicy. Obiekt-słowo został ograniczony do roli symulakru i nie wskazuje na realną postać, odnosi się wyłącznie do samego siebie: „ЧЕЛОВЕК(размахивает тростью). Жорж, я искал вас.. Никто не знает.. Был ЧЕЛОВЕК - и нет человека. Пропал бесследно..".

D’Anthes twierdzi, że był d'Anthesem. Teraz chodzi zaniedbany, nie uśmiecha się, miewa napady płaczu, jest słaby fizycznie. Bogajew, kreując tę postać (całkowicie przeczącą powszechnej opinii o znanym w XIX wieku baronie), zupełnie zburzył utrzymujący się przez wiele lat stereotyp doskonałego oficera, silnego, przystojnego uwodziciela, do którego wzdychało wiele kobiet. W jednej chwili udaremnił oczekiwania odbiorcy, jego gotowość na pojawienie się niesamowitego bohatera.

ЧЕЛОВЕК. [...] (Смотрит). Барон, какого черта вы так скверно выглядите?.. Вы действительно Жорж Шарль ДАНТЕС?..

ДАНТЕС. Был.

ПУШКИН. Что значит - был?

ДАНТЕС. То и значит.

ПУШКИН. Ну это философия.. Был- не был.. Меня интересует конкретика, а не ваши душевные излияния..

W podobnej sytuacji znajduje się też postać nazwana Człowiekiem, która przedstawia się jako potomek wielkiego pisarza - Aleksandra Puszkina. W świadomości rosyjskiego czytelnika na bardzo długo zakorzenił się wizerunek małego, znieważonego męża nietuzinkowej piękności, klasyka literatury rosyjskiej ze zranioną ambicją. W Bogajewowskiej sztuce jest pewnym siebie,

25 Uogólnienie nazw własnych po raz kolejny pojawia się w utworach Olega Bogajewa (np. Starzec i Starucha). Początkowo autor pozbawia swoje postaci tożsamości. 
dążącym do wyznaczonego celu mężczyzną. Szuka d'Anthesa, by w końcu wyzwać go na pojedynek. Bogajew podwaja obraz jednej i tej samej postaci - poety oraz jego syna, który stara się wypełnić to, czego nie udało się dokonać ojcu. Po raz kolejny komizm pojawia się w momencie naruszenia granicy pomiędzy stereotypowym wyobrażeniem o literackiej i biograficznej sylwetce postaci a jej obrazem, pośrednio odwołującym się do Puszkina i d'Anthesa.

Zachowanie jednej z głównych postaci wywołuje efekt komiczny. W chwili grozy, powagi, gdy zapowiada walkę na śmierć i życie, wymachuje kijem, plamiąc rękaw w kałuży tłuszczu: „ЧЕЛОВЕК. [...] Чёрт.. Поналивали тут.. (оттирает)”. Pojedynek to wydarzenie, które w żadnym razie nie wpisuje się w realia XXI wieku. Jest absurdalne w swojej istocie, przybiera farsowy charakter. Mamy tu przykład naruszenia granic między wydarzeniem kulturowym, rytualnym, należącym do określonej epoki a wypowiedziami postaci sztuki Bogajewa. Współczesnym obrazom Puszkina i d'Anthesa brakuje swoistej odwagi, odpowiednich cech charakteru, którymi powinni odznaczać się śmiałkowie, stający do pojedynku. Bohaterowie woleliby raczej zaprzyjaźnić się ze sobą niż do siebie strzelać. Według Henriego Bergsona przeniesienie starego do czasów współczesnych zawsze śmieszy odbiorcę ${ }^{26}$. Doskonale rozumie to sam Puszkin: „ЧЕЛОВЕК. [...] Понимаете? Нет? Разумеется, трудно представить в наше время такое странное мероприятие...”.

W czasach, kiedy media kierują świadomością człowieka, wiele sytuacji jest aranżowanych dla samego rozgłosu, sensacji, show, co wielokrotnie staje się obiektem drwin w sztuce. Puszkin pragnie, by pojedynek odbył się przy świadkach, dlatego zaprasza telewizję. Chce zorganizować publiczny spektakl, który stałby się symbolem wyjścia poza granice jego prywatności27. Reżyser zdaje sobie sprawę, że całe to zajście, sceneria, okoliczności, jak i sam pojedynek między „potomkami” d'Anthesa i Puszkina, to czysta komedia. Wyreżyserowanie oraz realizacja tego wydarzenia, jak również powielanie go w nieskończoność, jest nie do przyjęcia. Nikt z widzów w to nie uwierzy.

26 А. Бергсон, Смех, 1992, s. 66 [online, 30.08.2019].

27 W rzeczywistości Puszkin bał się, że jego spór z d'Anthesem, jak i sam pojedynek, staną się tematem rozmów szerszego grona publiczności, dlatego to wydarzenie odbyło się bez zbędnych obserwatorów. 
Dostrzegamy tu granicę między scenariuszem planowanego show a stosunkiem do pamięci o Puszkinie, jaki panuje w społeczeństwie.

Zdaniem Marka Pieczyńskiego, kultura wypiera rzeczywistość, gdyż okazuje się, że bohaterami nie kieruje rządza zemsty, a chęć odnowienia tradycji literackiej w duchu popkulturowej estetyki. W antytotalitarnej przestrzeni kultury postmodernistycznej pojedynek, będący rozwiązaniem romantycznego konfliktu między dwiema różnymi pozycjami, okazuje się niemożliwy28: „КИНОРЕЖИССЁР: По-вашему, я снимаю комедию? [...] Это не наша форма. Это - насмешка. [...] Кроме этого, унижение, если хотите, памяти нашего великого творца".

W sztuce przekroczono przede wszystkim granice historii. Prawdziwe zdarzenia, jakie miały miejsce w 1837 roku, zostały przeniesione do czasów współczesnych. Bogajew podjął próbę ich aktualizacji. Postacie historyczne, wykreowane uprzednio na kształt bohaterów komiksu (przez co utraciły swój wysoki status i autorytet), stały się bohaterami najnowszego dramatu rosyjskiego. Autor pominął poniekąd postać d'Anthesa, gdyż umieścił go jedynie w wyobraźni potomka prawdziwego Puszkina. Ograniczył go do słowa, symulakru. Wynika z tego, że naruszono tu granice znaczacego i znaczonego, ponieważ osoby d'Anthesa nie pokazano w komedii jako prawdziwego człowieka. Początkowo odizolowano od niego jego Głos, następnie ograniczono do nazywania Mężczyzną, co wskazuje na groteskowość postaci.

Bardzo wyraźnie została podkreślona narodowość Puszkina jako Człowieka z Rosji. Człowiek, pisany wielką literą, w dodatku Rosjanin, przedstawia się jako ktoś niezwykle ważny. D’Anthes ironizuje, chłodzi zapędy Aleksandra Siergiejewicza. Okazuje się, że pomimo silnej więzi ze swoim krajem Puszkinowi brakuje rosyjskości - bohater nie lubi tradycyjnych rosyjskich blinów. Zaskoczeniem jest, gdy wyznaje prawdę: nie jest Rosjaninem, lecz Amerykaninem. Twierdzi, że ciężko jest wytrzymać w Rosji dłużej niż tydzień:

ПУШКИН [...] Россию трудно терпеть больше недели. «Душа, доброта, сердечность».. Одни разговоры... Бессилие умственных способностей -

28 М. Печински, Образы литераторов-классиков в новейшей русской драматургии, „Вестник Самарского университета. История, педагогика, филология” 2018, Том 24, nr 2, s. 97 [online, 15.09.2019]. 
факт географический. Уверяю Барон, если бы предки мои остались в России, сидел бы перед вами маргинальный скот... В лучшем случае - беременный учитель. Сентиментальный бред.

W wypowiedzi postaci, pokazującej zniechęcenie i dystans do Rosji, naruszona została granica mentalnego stereotypu prawdziwego Rosjanina: ceniącego tradycję, silnego, kochającego swój kraj.

W sztuce Kto zabit monsieur d'Anthesa odbiorca styka się z wieloma absurdalnymi sytuacjami. Absurdalna jest również sama przestrzeń i okoliczności, w jakich spotykają się główne postaci: stary, opuszczony dom z rozpadającymi się schodami i drzwiami, które z łatwością wypadają z futryny. Wszędzie pełno osypującego się tynku, porozrzucanych kawałków marmuru i cegieł. W jednym z pomieszczeń leży przewrócony na bok fortepian. Miejsce w żaden sposób nie jest dostosowane do tego, by nakręcić wystarczająco realistyczny, oparty na faktach film dokumentalny o historycznym pojedynku. Sami bohaterowie nie potrafią wcielić się w role aktorów, nie przygotowują się do nakręcenia sceny, brakuje im konsekwencji w działaniu.

Bardzo często w Bogajewowskich sztukach pojawiają się postacie, które stały się literackim mitem lub uległy mitologizacji w świadomości człowieka końca XX wieku, osoby ze świata literatury, których dorobek jest ceniony na całym świecie. W dramacie Martwe uszy, czyli historia papie$r u$ toaletowego jednymi z głównych bohaterów są czterej mitologizowani przedstawiciele klasyki literatury rosyjskiej, fantomy pisarzy Czechowa, Tołstoja, Gogola i Puszkina. Nie są to postacie, które można postrzegać $\mathrm{w}$ odniesieniu do biografii realnie żyjących w XIX-XX wieku autorów. Mimo że odgrywają kluczową rolę w sztuce Bogajewa, dramaturg nie umieścił ich nazwisk w spisie postaci utworu: „Независимо от индывидуальной характеристики все они представляют собой общий персонаж по имени «великий русский писатель»" 29 . Zostali oni przedstawieni tak, jak funkcjonują w stereotypowym wyobrażeniu przeciętnych obywateli rosyjskich. Niezwykle cierpią, gdyż czują się nikomu niepotrzebni i odrzuceni. Współcześnie nikt nie czyta i nie rozumie ich utworów. Na domiar złego, nie- 
dawno zamknięto pobliską bibliotekę, więc dostęp do ich twórczości został znacznie ograniczony.

Postacie pojawiają się kolejno w domu Ery Nikołajewny. Jej osoba znacząco wyróżnia się spośród pozostałych bohaterów dramatu. Kobieta została przedstawiona jako przesadnie dużych rozmiarów bezduszna istota, zauważana w tłumie jedynie dzięki cechom fizycznym. Bogajew nazywa ją po prostu Człowiekiem, choć różni się ona znacząco od postaci Człowieka z wyżej omawianej sztuki. W tym przypadku ze względu na swoje specyficzne przymioty dramaturg przedstawił bohaterkę niczym rzadki gatunek biologiczny. Jedynym sensem życia Ery Nikołajewny, jak dotychczas, było nieustanne poszukiwanie jedzenia. Rozwój duchowy został całkowicie pominięty. Jej postać jest komiczna nie tylko ze względu na wygląd, który przekracza wszystkie ogólnie przyjęte w ludzkiej świadomości normy i wyobrażenia, lecz także sposób zachowania. Człowiek, z którym początkowo rozmawia, nazywa ją najmądrzejszą i najbardziej wykształconą kobietą w okolicy. Wyolbrzymiając i przejaskrawiając jej inteligencję, Bogajew jednocześnie ironizuje niekompetencje i brak chociażby ogólnej wiedzy współczesnego społeczeństwa na temat literatury rosyjskiej. W świadomości typowego, nie umiejącego czytać obywatela rosyjskiego, symbole literackie (wielkiej literatury rosyjskiej), które zostały poddane upersonifikowaniu, nagle ożywają - materializują się w sposób, jaki widzi świat Era Nikołajewna. Wszystkie postacie dużo jedzą i myślą o jedzeniu. Bogajew w sposób groteskowy doprowadza do paradoksu stereotyp mentalności Rosjanina. Jedzenie oraz proces spożywania zostają doprowadzone do granic absurdu. Między wieloma planami wyobrażenia o człowieku oraz tym, jak wyobraża go sobie Era Nikołajewna, pojawia się rozłam, będący źródłem ironii.

Pierwszy nieznajomy ${ }^{30}$ to fantom Antoniego Czechowa. Wdając się w dyskusję z Erą Nikołajewną, znajduje z nią wspólny język, prezentuje swoje umiejętności, byle tylko kobieta przygarnęła go do siebie. Chce być znów potrzebny i doceniony:

\footnotetext{
ЧЕХOВ. Чем займемся?

ЭРА. $\quad$ А что ты можешь?
}

30 Warto podkreślić, że na tym poziomie również pojawia się ironia. Czechow, znany na całym świecie, okazuje się całkowicie obcym dla przeciętnego rosyjskiego obywatela - Ery Nikołajewny. 
ЧEXOB. Я могу гладить белье, стирать, могу дом сторожить, ходить за младенцами и стариками. Могу готовить рагу из кролика, читать вслух. Наконец, могу лечить тиф. И сыпной, и брюшной, и возвратный.

„Wskrzeszając” na nowo do życia przedstawicieli rosyjskiej literatury klasycznej, Oleg Bogajew przekroczył granicę życia i śmierci. Postacie jako symulakry pojawiają się nie wiadomo skąd i zachowują niczym żywi ludzie: rozmawiają, jedzą, czują ból. Autor dosłownie pokazał odbiorcy nieśmiertelność pisarzy, o czym mówi sam Czechow:

ЧЕХОВ. Я хочу сказать вам по секрету, Эра Николаевна...

ЭРА. Говори.

ЧЕХОВ. Писатели бессмертны...

ЭРА. Bсе???

ЧЕХOB. Нет. Самые лучшие.

ЭРА. И Ты?

ЧЕХOB. Я.

W świadomości postaci autor wzbudza komiczne wyobrażenie o tym, co duchowe i fizyczne, powszednie i wzniosłe. Wśród rozbieżności między tymi przeciwstawnymi planami pojawia się ironia. Granica rysuje się pomiędzy znaczeniami metaforycznymi a dosłownymi, między tym, co wzniosłe i groteskowo sprofanowane.

Ponadczasowość i nieprzemijalność to przymioty zarówno pisarzy, jak i powstałej dzięki nim literatury. Współcześni odbiorcy, tacy jak Era Nikołajewna, którzy nie potrafią dostrzec mądrości płynącej z dawnej twórczości literackiej, doprowadzili do jej upadku: „ЭРА. Библиотеку, видишь ли, закрыли! А я что? Была на вас мода, да вышла!”. Kobieta uważa, że jest to tylko kwestia mody, która ciągle się zmienia. Kiedyś klasycy byli popularni, chętnie czytywani, jednak teraz przyszedł czas na zmiany.

Natalia Titkowa i Jekaterina Jesina w swojej pracy tłumaczą, że dramaturdzy współcześni, w tym Bogajew, starają się zrozumieć i odzwierciedlić w swoich sztukach skomplikowaną rzeczywistość czasów postsowieckich. W tym celu posługują się między innymi motywami Apokalipsy, samotności 
i głuchoty, a ich bohaterowie funkcjonują w dwóch światach: realnym i nierealnym ${ }^{31}$.

Motyw głuchoty jako główny w sztuce został wyodrębniony już w samym tytule utworu (ironiczne odniesienie do Martwych dusz Gogola), wskazując na „martwe uszy” współczesnego człowieka, niezdolnego do dialogu z innymi ludźmi. Wyłącznie Era Nikołajewna „słyszy” klasyków. Badaczki podkreślają, że w poszczególnych słowach tytułu nastąpiła zmiana znaczenia leksykalnego. Według nich motyw głuchoty został przedstawiony przez autora głównie dzięki zabiegowi ironicznego cytowania, który Nadežda Kovylâeva uważa za najpopularniejszy sposób tworzenia gry językowej w literaturze postmodernistycznej ${ }^{32}$.

Motyw samotności Bogajew prezentuje na przykładzie Ery Nikołajewny jako naruszenie normy ludzkiego życia. Kobieta mieszka sama, rozmawia z książkami, co doprowadza ją do obłędu: „В её голове возникают образы писателей, и в конечном итоге она сходит с ума. Так возникает ещё один мотив - помешательство главных героев, как реакция на одиночество" 33 .

Już w pierwszych wypowiedzianych replikach naruszona zostaje granica między rzeczywistością i światem fantastycznym. Odbiorca sztuki niepostrzeżenie trafia do świata, w którym klasycy literatury rosyjskiej są wciąż żywi, choć tak naprawdę ich życie stało się bardzo prymitywne. Na wzór Ery Nikołajewny jako konstrukt jej świadomości ograniczają się do podstawowych potrzeb. Są głodni, więc proszą o jedzenie. Nie mają dokąd pójść, więc zamieszkują u niej. Odbiorca, chcąc czy nie, uczestniczy w tym życiu, jest świadkiem absurdalnych zdarzeń, niezauważenie przekracza granicę dwóch światów: literackiego świata fikcji i pseudorealnego świata ludzi. Ironia występuje tu na poziomie absurdalnej transformacji: $\mathrm{z}$ „martwych” symulakrów tekstu klasycy zamieniają się w pseudożywych ludzi z prawdziwymi potrzebami.

31 Н. Титкова, Е. Есина, Доминантные мотивы пьесы О. Богаева «Мертвые уши, или новейшая история туалетной бумаги», „Филологические науки. Вопросы теории и практики” 2014, nr 10 (40) часть 1, s. 189 [online, 03.08.2019].

32 Н.Е. Ковыляева, Игровая действительность постмодерна, „Филологические науки. Вопросы теории и практики" 2013, nr 1 (19), s. 101 [online, 30.08.2019].

33 Н. Титкова, Е. Есина, Доминантные мотивы пьесы, dz. cyt., s. 190 [online, 03.08.2019]. 
W tej samej sytuacji, co Czechow, znalazł się także Lew Tołstoj. On również szuka ratunku w osobie Ery Nikołajewny. Bogajew początkowo nazywa go Starcem: „СТАРИК (косит взглядом на полное собрание Чехова, лежащее у стола). Здесь что, уже занято? (Bстает, представляетcя.) Граф Лев Николаевич Толстой. Великий русский писатель. Родился в двадцать восьмом, а помер в десятом по старому”. Oprócz niego w sztuce pojawia się Mikołaj Gogol i Aleksander Puszkin. To właśnie Puszkin ponownie przeżywa swoje ostatnie dni po pojedynku z d'Anthesem ${ }^{34}$. Okoliczności, w jakich umierał naprawdę, różniły się od tych przedstawionych przez autora. Bogajew nie starał się oddać realiów życia i śmierci żadnego z klasyków. Nie zostali oni pokazani jako prawdziwi ludzie, lecz jako uosobienie „wiecznie żywej" literatury, która nie pozwala o sobie zapomnieć. Gogol w rozmowie z Erą Nikołajewną sam przyznaje, że nie jest człowiekiem, inaczej by się z nią ożenił: „ГОГОЛЬ (восхищенно). Был бы я человек, я на вас бы женился мгновенно!”.

Dama w berecie, która przychodzi do domu Ery Nikołajewny na jej pisemną prośbę o pomoc materialną, jest zdumiona faktem, że Puszkin jest nieśmiertelny:

\section{ДАМА-БЕРЕТ (наклонилась к кровати, разглядывает). Господи ... Живой Пушкин?!!! \\ ЭРА. Ж Живой... Есть у нас Пушкин.}

ДАМА-БЕРЕТ. ОН же того ... Умер давно ... Убит на дуэли... (Изумленно смотрит.) Это как получается? Пушкин бессмертный???

Kluczowym słowem jest tu owa „nieśmiertelność”, dla której nie istnieją żadne granice. Pewną granicę jednak możemy wyznaczyć w związku z wewnętrzną formą tego wyrazu: nie-śmiertelność, czyli zaprzeczenie śmierci. Kobieta wyraźnie zastanawia się nad jego dosłownym znaczeniem, choć autor użył go w sensie przenośnym. Oksymoron w świadomości przeciętnego obywatela traci całościowe znaczenie - jego sens zawiera się w dwóch oddzielnych słowach. Innym przykładem dosłownego rozumienia słów jest sytuacja,

34 Po raz kolejny Bogajew odnosi się do historycznego pojedynku Puszkina i d'Anthesa, na którym opiera się sztuka Kto zabił monsieur Dantesa. 
kiedy Era Nikołajewna nie potrafi uświadomić sobie, kim był d'Anthes. Zadaje banalne, lecz szczere pytania: „ЭРА: Что такое Дантес? Болезнь или человек?". Sama też tak naprawdę nie wie, kim jest (był) Aleksander Puszkin. Mówiąc o nim, na myśl przychodzą jej różne skojarzenia. Przyznaje, że był jej towarzyszem od najmłodszych lat, uczyła się o nim w szkole, a pod jego pomnikiem spotykała się z narzeczonym. Opowiada o nim jak o kimś, kogo znała osobiście: „[...] Он мне как товарищ из рОдного детства”. Wspominając dzieciństwo Ery Nikołajewny, Bogajew podkreślił jednocześnie fakt, że była samotna, na co wskazuje zapis graficzny słowa „родной”. Należy tu zwrócić uwagę, że bohaterowie niejednokrotnie używają słów, nie traktując ich jako nośnika znaczeń, wskazujących na przedmiot bądź podmiot. Zamiast tego wchodzą w relacje ze słowem jako przedmiotem, składającym się z konkretnych liter.

„Nieśmiertelny” jest zawsze i wszędzie, nie można go ograniczyć w ramach czasowych. Każdy z pisarzy pozostawił na ziemi cząstkę siebie - dzieła, niejednokrotnie powielane i analizowane. Poruszany przez Bogajewa problem sam w sobie nie jest komiczny. Komiczne zaś są okoliczności i postać Ery Nikołajewnej, na którą spadł obowiązek opieki nad literatami. Bohaterka używa prostych słów i tylko takie rozumie. Nieświadomie miesza pojęcia, a jej przejęzyczenia, wypowiadane jak najbardziej poważnie, wywołują efekt komiczny:

CBETA. Вот. А потом библиотеку закрыли ...

ЭРА. Что же мне теперь с книжками делать?

CBETA. У меня мальчик родился.

ЭРА. Я интеллигенции писала, но от них эрекции никакой.

Era Nikołajewna nadzwyczaj dobrze opiekuje się samymi pisarzami. Doskonale wie, co każdy z nich lubi, jakie są ich przyzwyczajenia, czego potrzebują. Odmawia sobie jedzenia, by móc nakarmić podopiecznych. Zachowuje się jak ich matka, gotowa poświęcić samą siebie. Choć zewnętrznie niedoskonała, Bogajew przedstawił ją jako odważną kobietę. Dokonał tego W sposób ironiczny, śmiejąc się ukradkiem z русской женщины (роје̨сіе zarówno bardzo ogólne, jak i literackie). Era Nikołajewna, przedstawiona jako symbol epoki, „nowej” ery, stała się także symbolem współczesne- 
go człowieka ${ }^{35}$. Wraz z biegiem wydarzeń bohaterka przechodzi widoczną metamorfozę. Rozmawiając z klasykami, nabywa doświadczenia nie tyle w kontaktach z drugim człowiekiem, co z klasyczną literaturą rosyjską.

W sztuce pojawia się jeszcze jedna postać, bardzo charakterystyczna dla współczesnego świata. Jest to pisarz Suslenko, który zdobył literacką Nagrodę Nobla. Nazwisko bohatera ewidentnie pochodzi od nazwy małego zwierzęcia (rosyjskie суслик - suseł), prawie niezauważalnego. Według niego w pracy liczy się jedynie rezultat i nieważne, w jaki sposób się go osiągnie. W ciągu pięciu minut napisał powieść o Erze Nikołajewnie Сумасшедщая Эpa, udowadniając, że nie wkłada serca $\mathrm{w}$ to, co robi, pracuje machinalnie: „СУСЛЕНКО. В литературе главное - результат, а сердце пригодится для жизни".

Bohaterka dostała ogromną szansę uratowania chociażby części książek Czechowa, Tołstoja, Gogola i Puszkina. W finale sztuki pojawia się motyw Apokalipsy: zniknięcie klasyków oznacza koniec świata ${ }^{36}$, a Era Nikołajewna trafia do zakładu psychiatrycznego. Cały dorobek literacki pochłonął ogień:

Горы книг. [...] Заскрипели буквы. Лопнули шелковые нити. Книги набухают как дрожжевое тесто. Гром. Это не склад боеприпасов - книги разрываются огнем одна за другой. Огонь кружит по комнате. За окном падает черный снег или это типографский работник пошутил с крыши?

В пламени скачет медный всадник, шинель размахивает пустыми рукавами, детство-отрочество-юность стоят, прижавшись друг к другу, горящая чайка бьется в окно.

Skrzypiące litery, pękające nici, pęczniejące książki - to przykłady metafor, które ponownie uległy uprzedmiotowieniu. Kobiecie nie udało się uratować dorobku literackiego rosyjskich klasyków. Tragiczne zakończenie sztuki pozwala wywnioskować, że mimo wszelkich starań Era jako jednostka nie była w stanie zapobiec zagładzie. Zgodnie ze słowami Haliny Mazurek,

35 E. Cempa, Postmodernistyczna „rzeczywistość” wedlug Olega Bogajewa a ponowoczesne znamiona Nietzscheańskiej kultury, „Rusycystyczne Studia Literaturoznawcze” 2012, nr 22, s. 153.

36 Н. Титкова, Е. Есина, Доминантные мотивы пьесы, dz. суt., s. 189 [online, 03.08.2019] 
[...] pozostaje więc Era Nikołajewna tylko symbolem czasów minionych, przeżytkiem, dla którego nie ma już miejsca w dzisiejszej skomercjalizowanej cywilizacji, tak jak nie ma miejsca dla starych woluminów na półkach nowej biblioteki, gdzie wzrok przykuwają nic nie znaczące utwory groteskowego noblisty Suslenki oraz kolorowe książki z obrazkami w rodzaju Biblii smacznych i zdrowych potraw ${ }^{37}$.

Przedstawiona przez Bogajewa wizja końca świata, zupełnie absurdalna, staje na pograniczu literatury i metaforycznego postrzegania rzeczywistości. Sami geniusze, w tym także wielcy pisarze, uosabiają naruszenie pewnych norm, granic, będących wyznacznikiem swoistej normalności w człowieku. Tacy ludzie są raczej postrzegani jako niestabilni emocjonalnie szaleńcy. Anna Merežinskaâ przeanalizowała tę ostatnią, fantasmagoryczną scenę sztuki, opierając się na zjawisku mitologizacji. Zauważa, że odnosi się ona do sceny pożegnania orszaku Wolanda z Moskwą. Pojawiają się również wyrwane z kontekstu obrazy, epizody utworów rosyjskich klasyków. Badaczka podkreśla, że dramaturdzy w procesie mitologizacji wykorzystują różne obrazy i wzorce, zarówno tradycyjne (mity eschatologiczne), jak i bardziej współczesne, szukają nowych pomysłów ${ }^{38}$.

Piekło Stanisławskiego. Zwykła historia w jednym akcie $e^{39}$ to intertekstualny tytuł sztuki Olega Bogajewa, inspirowany Wiśniowym sadem Antoniego Czechowa. Komedia została napisana w 2010 roku i jest kolejnym utworem uralskiego dramaturga, poruszającym problem współczesnego teatru i literatury. W tytule autor informuje odbiorcę, że tak naprawdę sztuka nie odnosi się bezpośrednio do utworu Czechowa, a do niepowodzeń, związanych z wielokrotnymi próbami jego inscenizacji.

Sztuka zaskakuje ubogą dekoracją sceny, przedstawiającą opustoszały, marsjański krajobraz. To miejsce nie wzbudza żadnych pozytywnych emocji,

37 H. Mazurek, Dramaturdzy z Jekaterynburga. ,,Szkoła” Nikołaja Kolady, Katowice 2007, s. 34.

38 А.Ю. Мережинская, Стратегии мифологизаиии литературы в русской прозе и драматургии 2000-х гz., „Русская литература. Исследования” 2011, nr 15, s. 106 [online, 10.09.2019].

39 Początkowo sztuka nosiła tytuł Вишнёвый ад Станиславского, jednak później Bogajew skrócił ją do Piekła Stanisławskiego. Została opublikowana po raz pierwszy w czasopiśmie „Ural” w 2010 roku. 
wręcz przeciwnie: jest zimne i straszne. W takich okolicznościach trwają przygotowania do inscenizacji Wiśniowego sadu Czechowa ${ }^{40}$. Na łamach gazety „Prawda”, „Kultura” i „Wiadomości” zostają zamieszczone oskarżające teatr i reżysera wpisy. Pracownicy teatru przedstawiają je reżyserowi Kuricynowi, tym samym zrzucając na niego odpowiedzialność za wszelkie niepowodzenia, które ich dotąd spotkały:

Л о ра Прун. «Серьезный, глубокий психологический театр подменяется скоропортящимися поделками или антрепризой, о чём писали и уважаемые театральные критики (Р. Жбанский, и М. Дмыдова)».

Ф ляги н. «Русский театр, долгие годы служивший храмом человеческих чувств, превращается в «дикий могильник» эпохи бесстыдства, о чем ярко свидетельствует предстоящая премьера в нашем театре с диким названием «Вишневый зад».

Powyższy fragment to przykład ironicznej refleksji odnośnie do teatru ogółem, jak i w szczególności inscenizacji Czechowa. Problem stanowi brak kompetencji aktorów oraz sposób, w jaki postacie ze sobą rozmawiają. Po jednej stronie są pracownicy teatru i aktorzy, po drugiej - reżyser Kuricyn. Nie potrafią się ze sobą dogadać, jedni drugim ubliżają. Reżyser traktuje ludzi jak podwładnych, nie liczy się z ich zdaniem, zarzuca im brak umiejętności. Aktorzy zaś nie chcą słuchać uwag Kuricyna, wolą pracować bez niego:

Р е ж и с с е р. Это решать управленью культуры. А вы всего лишь актеры. Актеры! И ваша задача на сцене играть! А «цеховые» должны помогать! А кто не согласен, пусть валит к черту!

С а й д ул л а е в. У нас профсоюз.

Р е ж и с с е р. Да в жопу ваш профсоюз! Вы голоса не имеете! Имеют они... (Указывая на корифеев.) Одной ногой в могиле и за собой тащат театр...

К о р н е е в (знак в будку радистке). Алён, микрофончик...

40 Warto podkreślić, że nieudane inscenizacje sztuk Antoniego Czechowa, w tym także Wiśniowego sadu, zakorzeniły się już w stereotypowym odbiorze życia teatralnego Rosji, stały się jego normą. 
W Piekle Stanisławskiego autor ukazał konflikt związany z przezwyciężeniem dyktatu inscenizacji teatralnych - w tym przypadku dyktatury interpretacji sztuk Czechowa. Trzynasty reżyser (tak jak wszyscy jego poprzednicy) jest postrzegany przez aktorów oraz pracowników teatru jako tyran, który bez względu na jakiekolwiek uwagi dąży do zrealizowania zamierzonego celu. Doprowadza to do buntu przeciwko totalitarnemu reżimowi, którego uosobieniem stał się sam reżyser. Aktorzy negują sposób, w jaki próbuje on zinterpretować sztukę Czechowa. Na znak protestu postanawiają zabić reżysera i dokonać na nim aktu kanibalizmu. W sposób farsowo-alegoryczny organizm teatralny uległ poważnej deformacji, co powoduje naruszenie granicy wyobrażeń o normach ludzkiego zachowania ogółem i relacji pomiędzy aktorami i reżyserem, w szczególności. Próba zjedzenia Kuricyna została w utworze zwizualizowana:

К о р н е е в. [...] Великий основатель нашего театра Владимир Иванович Лялин на заре XX века достаточно точно выразил свою мысль в письме к Горькому: «Для чего нужны режиссеры? Для того, чтобы их есть. На этом и держится наш русский театр». В этой регулярности и непрерывающейся великой традиции мы принимаемся за 13-го режиссера. (Убирает бумагу в карман.)

Д и ф ф е н 6 а х. Нy?..

К о р н е е в. Начинайте!

Звучит «реквием». Диффенбах берет топор, подходит к лежащему режиссеру. Входит буфетчица с тарелками и вилками.

Р е ж и с с е р. Я не съедобный... (Кричит.) я не съедобный!!!

Metafora „zjeść kogoś” uległa materializacji, nabrała w sztuce Bogajewa dosłownego sensu. W związku z tym po raz kolejny dochodzi do naruszenia granicy na poziomie semantycznym: sens przenośny został odebrany przez pracowników teatru dosłownie, co wywołuje efekt komiczny.

Analizowana sztuka jest utworem metateatralnym (termin wprowadzony przez Lionela Abla w 1963 roku), podobnie jak komedia Kto zabit monsieur d'Anthesa. Patrice Pavis definiuje pojęcie metateatralności jako „przedstawienie lub dramat o charakterze autorefleksyjnym, którego tematyka skoncentrowana jest wokół spraw teatru; sztuka dramatyczna, która „mówi” o samej 
sobie czy też „przedstawia się sama”41. W sztuce Bogajewa bohaterami są między innymi osoby ze środowiska teatralnego, aktorzy, a także widzowie - fantomy postaci Czechowa i Stanisławskiego. Możemy zatem mówić tu o formie metateatralności, jaką jest „teatr w teatrze”, „którego zaistnienie wiąże się z pojawieniem się podziału personelu dramatycznego na postacie-aktorów i postacie-widzów, a przestrzeni na scenę wewnętrzną i zewnętrzną"42.

W Piekle Stanisławskiego znajdziemy również zachwianą granicę między życiem i śmiercią. Po raz kolejny bohaterami sztuki Bogajewa są klasycy literatury rosyjskiej. Przedstawianie ożywających postaci stało się u dramaturga lejtmotywem, łączącym wszystkie omawiane powyżej utwory. Antoni Czechow, obserwujący starania reżysera wraz z Konstantinem Stanisławskim i Aniołem Stróżem Kuricyna, wskrzesza go do życia, dając tym samym kolejną szansę na przygotowanie inscenizacji:

Режиссер оживает, как ни в чем не бывало, встает на ноги. Все замирают, пораженно глядят на него.

Реж иссер. Что, опять перекур??? (Бодро.) Репетировать! Репетировать! Мы не успеем! На сцену! [...]

С т ан и с л а в с к и й (Чехову). Зачем вы это сделали?!

4 е х о в. Мы должны дать ему последний шанс.

Tekst sztuki Czechowa przysparza wielu kłopotów Kuricynowi. Pomimo tego, że reżyser ma nową koncepcję przedstawienia sztuki, wpisującą się w realia postmodernistyczne, nie potrafi jej zrealizować. Granica zostaje wyraźnie naruszona w relacjach podmiotu z obiektem. Słowo pisane jest obiektem uwagi odbiorcy, a jednocześnie podmiotem, który zagraża reżyserowi. Posiada silne znaczenie performatywne, organizuje akcję sztuki.

Michał Pieczyński słusznie zauważa, że w Piekle Stanisławskiego z ontologicznego punktu widzenia funkcjonują trzy wzajemnie przenikające się światy ${ }^{43}$.

41 P. Pavis, Stownik terminów teatralnych, Wrocław 1998, s. 287.

42 K. Ruta-Rutkowska, Metateatralność, metadramatyczność, metatekstowość w dramacie, „Pamiętnik Literacki” 2010, nr 2, s. 116.

43 М. Печински, Образы литераторов-классиков в новейшей русской драматургии, „Вестник Самарского университета. История, педагогика, филология” 2018, т. 24, nr 2, s. 98 , [online, 15.09.2019]. 
Pierwszy to tekst właściwy sztuki Antoniego Czechowa Wiśniowy sad. Drugi - próby realizacji spektaklu Wiśniowy zad w reżyserii Kuricyna, co świadczy o metatekstualnym charakterze utworu. Jako ostatni badacz wymienia przestrzeń, w której wciąż jeszcze żyją Czechow i Stanisławski, autor i reżyser pierwszej inscenizacji Wiśniowego sadu. Są obserwatorami i komentatorami bieżących wydarzeń na scenie teatru. Granice między tymi trzema światami ulegają naruszeniu w momencie, kiedy fantom postaci Czechowa decyduje się na ingerencję w ponowne powołanie do życia Kuricyna.

Tytułowe piekło poniekąd materializuje się na scenie teatru podczas pracy Kuricyna. Ad zastąpił sad, a dekonstrukcja słowa niesie za sobą deformację świata i światopoglądu.

W działalności teatru i pracy reżyserskiej została utracona granica między tym, co moralne i niemoralne, humanitarne i niehumanitarne. Akt kanibalizmu, dokonywany na reżyserach pracujących w teatrze (co stało się już tradycją tego miejsca), jest wyrazem „zamiłowania” aktorów do sztuki. Obrzęd ten, praktykowany w XXI wieku, to wydarzenie całkowicie absurdalne, jednak tylko dla odbiorców sztuki. Obecni w teatrze aktorzy i pozostali pracownicy robią to świadomie, wcielając w życie metaforyczne wyrażenie „zjeść kogoś”.

Kategoria komizmu w sztukach Bogajewa została zrealizowana w różnych formach. Komizm dotyczy zarówno wątku, jak również zachowania i wypowiedzi postaci. We wszystkich wyżej przeanalizowanych sztukach została naruszona granica kategorii znaczace i znaczone: między tropami artystycznymi, powszechnym, szablonowym brzmieniem napisanych słów, jednością znaczenia metafory a ich dosłownym, wewnętrznym znaczeniem. Niezgodność tych planów przejawiała się w wielu wypowiedziach bohaterów, nie zawsze świadomych tego, o czym mówią.

Dramaturg zastosował grę językową również na poziomie tytułów niektórych utworów, dokonując różnych transformacji. „Martwe dusze” posłużyły mu za „martwe uszy” (sens dosłowny nie pokrywa się z sensem przenośnym), zaś „sad” Czechowa zamienił się w „ad” (rosyjskie „piekło”), a nawet „zad” (ze względu na czytanie sztuki „od tyłu”). W związku z tym pojawiła się granica między postrzeganiem słowa jako nośnika znaczenia a jego uprzedmiotowieniem (każda litera słowa może istnieć samodzielnie).

W powyższej analizie udowodniono, że obok przekroczenia granic norm językowych, niejednokrotnie zostały przekroczone także granice zasad moralnych. 
W momencie, kiedy Bogajew aktualizował wydarzenia z minionej epoki, doszło do przełamania barier historycznych. Wykorzystując fantomy, symulakry postaci już nieżyjących, niezauważalnie przekroczono granicę życia i śmierci, świata realnego i fantastycznego. W efekcie odbiorca tekstu doświadczył tzw. przeżyć ekstatycznych, które także wywołują wyobrażenie o czymś wzniosłym, doprowadzonym do egzaltacji w momencie pojawienia się farsowo-absurdalnego zjawiska.

\section{Bibliografia}

Bachtin M., Problemy poetyki Dostojewskiego, Warszawa 1970.

Bandurina N. S., Osobennosti interpretacii fenomena komičeskogo v istoriko-literaturnom i filosofskom kontekste, „Vestnik Ivanovskogo gosudarstvennogo ènergetičeskogo universiteta" 2011, (nr) 3, s. 1-6, [online], https://cyberleninka. ru/article/n/osobennosti-interpretatsii-fenomena-komicheskogo-v-istoriko-literaturnom-i-filosofskom-kontekste, [01.09.2019].

Bergson A., Smeh, 1992, [online], http://yakov.works/library/02_b/er/gson_smeh. htm, [30.08.2019].

Bogaev O., Russkaâ narodnaâ počta, [online], http://bogaev.narod.ru/doc/book.pdf, [10.06.2019].

Cempa E., Postmodernistyczna "rzeczywistość" według Olega Bogajewa a ponowoczesne znamiona Nietzscheańskiej kultury, „Rusycystyczne Studia Literaturoznawcze" 2012, nr 22, s. 148-157.

Dziemidok B., O komizmie, Warszawa 1967.

Grišanova E. V., Sociokul'turna mnogoaspektnost' $i$ istorizm kategorii komičeskogo, „Kul'tura i civilizaciâ” 2017, (nr) 2(6), s. 102-107, [online], https://cyberleninka. ru/article/n/sotsiokulturnaya-mnogoaspektnost-i-istorizm-kategorii-komicheskogo, [05.09.2019].

Iŝenko N. I., Hel'mut plesner: Smeh i plač, 2014, [online], https://www.phisci.info/ jour/article/view/828, [01.09.2019].

Kislova L. S., Funkcii komičeskogo v dramaturgii O. Bogaeva, „Vestnik TGPU” 2011, (nr) 7 (109), s. 175-179, [online], https://vestnik.tspu.edu.ru/files/vestnik/PDF/ articles/kislova_I._s._175_179_7_109_2011.pdf, [05.09.2019]. 
Kovylâeva N. E., Igrovaâ dejstvitel'nost' postmoderna, „Filologičeskie nauki. Voprosy teorii i praktyki" 2013, (nr) 1 (19), s. 101-104, [online], http://scjournal.ru/ articles/issn_1997-2911_2013_1_27.pdf, [30.08.2019].

Kratkij slovar' po èstetike, [online], https://cld.bz/users/user-12616383899/Kratkiislovar-po-estetike/76/, [15.10.2020].

Mazurek H., Dramaturdzy z Jekaterynburga. "Szkoła” Nikołaja Kolady, Katowice 2007.

Merežinskaâ A. Û., Strategii mifologizacii literatury v russkoj proze i dramaturgii 2000-h gg., „Russkaâ literatura. Issledovaniâ” 2011, (nr) 15, s. 103-125, [online], http://dspace.nbuv.gov.ua/ bitstream/handle/123456789/105463/09Merezhinskaya.pdf? sequence=1, [10.09.2019].

Pavis P., Słownik terminów teatralnych, Wrocław1998.

Pečinski M., Obrazy literatorov-klassikov v novejšej russkoj dramaturgii, „Vestnik Samarskogo universiteta. Istoriâ, pedagogika, fi"ologiâ" 2018, t. 24 (nr) 2, s. 93-100, [online], https://cyberleninka.ru/article/n/obrazy-literatorov-klassikovv-noveyshey-russkoy-dramaturgii, [15.09.2019].

Ruta-Rutkowska K., Metateatralność, metadramatyczność, metatekstowość w dramacie, „Pamiętnik Literacki” 2010, z. 2, s. 113-138.

Rymar' N., Poètika granicy v literature. Ėstetičeskie i poètologičeskie aspekty problemy granicy kak fenomena hudožestvennogo âzyka, Siedlce 2016.

Titkova N., Esina E., Dominantnye motivy p'esy O. Bogaeva «Mertvye uši, ili novejšaâ istoriâ tualetnoj bumagi», „Filologičeskie nauki. Voprosy teorii i praktyki" 2014, (nr) 10 (40) cz. 1, s. 189-191, [online], http://scjournal.ru/articles/ issn_1997-2911_2014_10-1_48.pdf, [03.08.2019].

Wachowski J., o komizmie, śmieszności i nie tylko..., [w:] Ko-mediana, Poznań 2013, s. $13-25$. 